\title{
ULRICH WOLLNER:
}

DOI: https://doi.org/10.31577/filozofia.2019.74.1.7

\section{Prolegomena k Platónovmu dialógu Gorgias}

Banská Bystrica: Belianum 2017, 73 s.

Publikácia Prolegomena k Platónovmu dialógu Gorgias predstavuje nový a originálny príspevok do diskusie o Platónovom dialógu Gorgias. Autor sa problematike venuje už dlhší čas 1 a predkladaný titul možno hodnotit' ako výsledok jeho dlhodobého záujmu a výskumu v danej oblasti.

Z istého uhla pohl'adu by sme mohli Wollnerovu prácu charakterizovat' aj z hl'adiska filozoficko-hermeneutického. Dialóg Gorgias patrí k historicky najpopulárnejším a najčítanejším Platónovým dialógom. Zasahuje nielen do oblastí politickej filozofie a etiky, ale aj rétoriky, estetiky, epistemológie, či dokonca mýtu a eschatológie. Nazdávame sa, že na Wollnerovej publikácii treba vyzdvihnút' najmä jej zámer, ktorým je poskytnút' čitatel'om predporozumenie filozofickým témam prítomným v Platónovom dialógu Gorgias.

V prvej kapitole (s. 6 - 14) sa pertraktuje problematika datovania vzniku dialógu. Na jednej strane môžeme uvažovat' o tom, kedy Platónov dialóg Gorgias vznikol - toto je problém absolútnej chronológie, ktorá sa usiluje nájst' konkrétny dátum vzniku dialógu. Autor upozorňuje, že ,stanovit' rozmedzie rokov, v ktorých mal Platón napísat' Gorgias, je nesmierne náročné“ (s. 8). Na základe konsenzu moderných interpretátorov môžeme s istou dávkou pravdepodobnosti určit' toto rozmedzie do obdobia 390 - 380 pred Kristom. Dialóg tak zrkadlí Platónove skúsenosti na Sicílii a predstavuje aj „kritickú reakciu na Isokrata“ (s. 10) a jeho chápanie filozofie. Na druhej strane vel'ká čast' prvej kapitoly sa venuje relatívnej chronológii Platónovho Gorgia, teda problematike toho, či bol Gorgias spísaný skôr alebo neskôr ako iné dialógy a aký má vzt’ah $\mathrm{k}$ iným dialógom $\mathrm{v}$ rámci celého platónskeho korpusu. V tejto otázke Wollner upozorňuje na viaceré možnosti, ku ktorým dospeli moderní bádatelia: Gorgias môže predstavovat' jeden z prvých dialógov, ktoré kedy Platón spísal (Kahn), aj ked’ je asi pravdepodobnejšie, že ide o takzvaný dialóg z tranzitívnej skupiny, teda z prechodnej skupiny medzi ranými (aporetickými) a strednými (dogmatickými) dialógmi, kam patria diela Menon a Faidon (Klosko). Autor d’alej analyzuje názory viacerých popredných odborníkov, akými sú Guthrie, Thesleff, Vlastos atd'. Aby sme si vedeli vytvorit' predstavu o autorovej erudícii, tak len na okraj uvedieme, že v prvej kapitole cituje Wollner až štyridsat’jeden titulov od tridsiatich štyroch zahraničných autorov.

Druhá kapitola (s. 15 - 18) sa venuje zaujímavej otázke dramaturgie

\footnotetext{
${ }^{1}$ Porov. napr. Wollner 2008 a 2010.
} 
Platónovho Gorgia. Wollner pred čitatel'om odhal'uje možné psychologické rozpoloženie Platóna ako autora textu, ktorý v Gorgiovi vyjadruje spomienku na nespravodlivé odsúdenie Sokrata. Gorgias svojou štruktúrou pripomína Euripidovu tragédiu Antiope a môže predstavovat' akúsi druhú verziu Sokratovej obhajoby, ktorou Platón reaguje na kritický pamflet Polykratovho diela Obžaloba Sokrata (s. 15 - 16). Dialóg sa odohráva v období peloponézskej vojny, s ktorou je „,blízko spojený“ (s. 17). Autor d'alej venuje pozornost' popisu publika a priestorov, v ktorých sa dialóg má odohrávat' (s. 17 - 18). Plasticky rekonštruuje málo známe aspekty sociálneho života filozofov a sofistov v klasickom období.

Tretia kapitola (s. 19 - 21) sa zaoberá štruktúrou dialógu. V platónskych štúdiách je štrukturalizácia Platónových dialógov obl'úbenou disciplínou, pretože $\mathrm{v}$ nejednom prípade sa v dialógoch dá určit' nielen matematická, ale aj tematická symetria. Wollner opät' uvádza celú paletu názorov moderných bádatel'ov, ktorí poukazujú na rôzne možné čítania dialógu. Na jednej strane upozorňuje na autorov (Jaeger, Kastely, Doyle, Liebersohn), ktorí dialóg rozdel'ujú na tri etapy podl'a troch rétorov a ich rečí. Tie symbolizujú tri stupne polemiky medzi rétorikou a filozofiou, ktoré sa „stupňujú svojou dĺžkou a intenzitou“ a vytvárajú tak dynamickú, no jednotnú argumentačnú štruktúru dialógu (s. 19 - 20). Na druhej strane upozorňuje na názory Tarranta a Thesleffa, podl'a ktorých dialóg obsahuje viaceré ruptúry a nie je až taký jednotný. Zdá sa, že celý rozhovor s Kalliklom bol dopísaný až ovel'a neskôr (s. 21).

Kapitola s názvom Postavy je najobšírnejšia z celej monografie (s. 22 - 52). Autor v nej detailne popisuje všetky postavy dialógu: Sokrata a jeho priatel'a Chairefóna (s. 22 - 32), Gorgia a jeho žiakov Pola a Kallikla (s. 32 - 52). Postava Sokrata v Gorgiovi nadobúda novú, pre väčšinu platónskych dialógov netypickú črtu: je ňou Sokratova neschopnost' presvedčit' spoludiskutujúcich, najmä Kallikla. Sokrates v závere dialógu prechádza k dlhým monologickým predslovom, uchyl’uje sa k rozprávaniu eschatologického mýtu a neúspešne apeluje na svojho partnera $\mathrm{v}$ diskusii, aby sa s ním d'alej rozprával (s. 28). Postava Chairefóna je mimoriadne zaujímavá, pretože Gorgias predstavuje ojedinelé miesto v platónskych dialógoch, kde Chairefón aktívne vystupuje a kde sa zúčastňuje diskusie. Chairefón sa ukazuje ako horlivý Sokratov stúpenec, ktorý je schopný viest' sokratovský dialóg s Gorgiom. Woll-ner upriamuje pozornost' najmä na to, že Chairefón tvorí v dialógu akýsi „stredný článok“ medzi Sokratom a Gorgiom - je sprostredkovatel’om celej diskusie a stretnutia (s. 32). Pri postave Gorgia dochádza Wollner k vlastnému záveru, že by sme túto postavu nemali podceňovat'. Platón ho totiž vykresl'uje ako naivného a tak trochu prostého dialektika, ktorý si protirečí, no ani o tom nevie. Toto je podl'a Wollnera spôsobené vonkajšími, teda „dramatickými““ okolnost'ami, ked' Gorgias nemôže pred aténskym aristokratickým publikom pripustit', že dobro a zlo nepatria do predmetu rétorického umenia (s. 37). Polos a Kallikles sú postavy $\mathrm{s}$ jasným negatívnym podtónom. Sú to Gorgiovi žiaci a z ich rečí možno vyčítat' sebavedomie, pýchu a pohŕdanie. Na rozdiel od staručkého Gorgia sa k Sokratovi nesprávajú úctivo, ale naopak, chcú ho za každú cenu znemožnit', dokonca medzi 
nimi ustavične hrozí hádka a konflikt. Tento odmietavý postoj voči Sokratovi si zachovávajú až do konca dialógu. Polos tak predstavuje ,jasný príklad toho, aké môžu byt' konzekvencie rétorického vzdelania“ (s. 42), zatial' čo Kallikles sa postupne premieňa na „odlúčeného cynického pozorovatel'a, ktorý necháva Sokrata hovorit', čo chce" (s. 52).

V piatej kapitole (s. 53 - 56) sa autor zamýšl’a nad otázkou, či dialóg Gorgias obsahuje len jednu hlavnú tému, alebo obsahuje viacero „kardinálnych“ tém. Po zhrnutí diskusií moderných bádatel’ov formuluje vlastný názor a argumentuje v prospech toho, že dialóg obsahuje viacero kardinálnych tém. Sú nimi „,problém rétoriky; problém spravodlivosti; otázka, či je lepšie páchat' nespravodlivost', alebo ju trpiet'; nadradenie filozofického života nad životom politickým; otázka starostlivosti o seba“" (s. 56).

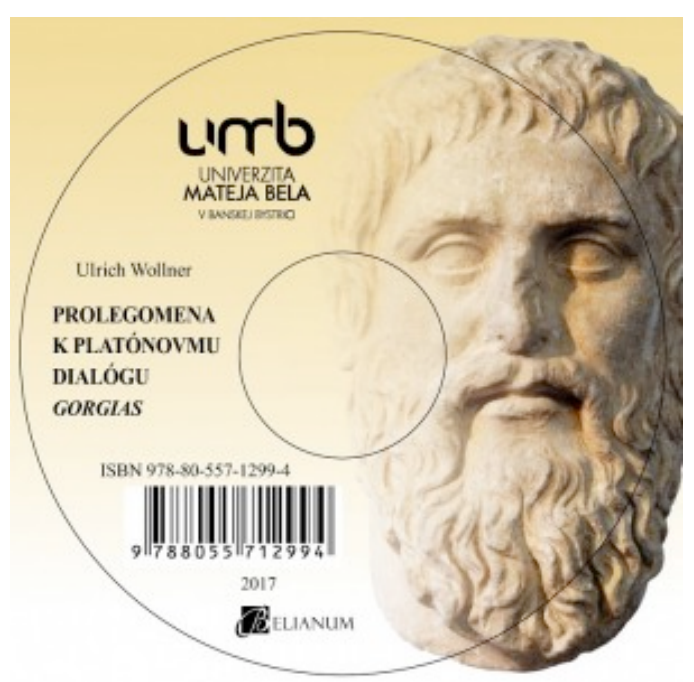

Z celkového hl'adiska predstavuje Wollnerova monografia štandardný príklad súčasného trendu v oblasti interpretačných zásad antických filozofických štúdií: prvý krok tkvie v čo možno najkomplexnejšej analýze interpretačnej literatúry, druhý $\mathrm{v}$ schopnosti kriticky zhodnotit' názory moderných bádatel'ov a formulovat' vlastné postoje a hypotézy. Po podrobnom prečítaní môžeme skonštatovat', že autor tieto ciele splnil. Práca je prehl’adná, až na dve výnimky (s. 21 a 49) neobsahuje žiadne štylistické či gramatické chyby a nepresnosti. Výhodou je tiež skutočnost', že publikácia vyšla elektronicky a je dostupná na CD nosiči. Jediným nedostatkom recenzovaného titulu je podla nás jeho obmedzený rozsah, ktorý autorovi neumožňuje detailnejšie rozobrat' niektoré zaujímavé témy a problémy, ale ani postoje niektorých interpretátorov.

Na záver si dovolíme pridat' ešte jednu poznámku. Prolegomena 2 kedysi predstavovali vrcholový žáner nemeckej vedy o klasickom staroveku (Altertumswissenschaft). Slúžili na vymedzenie hlavných interpretačných problémov, ktoré súvisia s dielami klasických autorov, a zároveň poskytovali prehl'ad názorov význačných bádatel'ov $\mathrm{k}$ danej problematike. Veríme, že Wollnerov titul nezostane len osamoteným exemplárom, ale stane sa základom a vzorom pre

\footnotetext{
${ }^{2}$ Doslovne preložené „to, čo sa hovorí pred“. Vol’nejšie by sme mohli výraz preložit' aj ako „veci, ktoré je potrebné povedat' pred štúdiom nejakého diela alebo spisu“.
} 
Prolegomena k d'alším Pla-tónovým dialógom, ktoré budú odhal'ovat' híbku a nadčasovost' odkazu tohto vel'kého filozofa.

\section{František Škvrnda}

\section{Literatúra}

WOLLNER, U. (2008): Platónov Sokrates o poézii a rétorike v dielach Ión a Gorgias. Filozofia, $63(1), 18-27$.

WOLLNER, U. (2010): Starost' o seba v Platónovom dialógu Gorgias. Filozofia, 65 (3), $227-238$

František Škvrnda ml.

Katedra medzinárodných politických vzt’ahov

Fakulta medzinárodných vzt’ahov

Ekonomická univerzita v Bratislave

Dolnozemská cesta 1

85235 Bratislava 5

Slovenská republika

e-mail: frantisek.skvrnda2@euba.sk 